Making the World Global 
This page intentionally left blank 


\section{Making the World Global}

U.S. Universities and the Production

of the Global Imaginary

ISAAC A. KAMOLA

DUKE UNIVERSITY PRESS

Durham and London

2019 
(C) 2019 Duke University Press

All rights reserved

Printed in the United States of America

on acid-free paper $\infty$

Designed by Matthew Tauch

Typeset in Minion Pro and TheSans $\mathrm{C}_{4} \mathrm{~s}$

by Copperline Book Services

Library of Congress Cataloging-in-Publication Data

Names: Kamola, Isaac A., author.

Title: Making the world global : U.S. universities and the production of the global imaginary / Isaac A. Kamola.

Description: Durham : Duke University Press, 2019.|

Includes bibliographical references and index.

Identifiers: LCCN 2018047266 (print)

LCCN 2019005716 (ebook)

ISBN 9781478005612 (ebook)

ISBN 9781478004172 (hardcover : alk. paper)

ISBN 9781478004738 (pbk. : alk. paper)

Subjects: LCsH: Education, Higher-United States-Finance. |

Universities and colleges-United States-Finance. |

Educational fund raising-United States. | Education and

globalization.

Classification: LCC LB2342 (ebook) | LCC LB2342 .K34 2019

(print) | DDC 378.1/060973-dc23

LC record available at https://lccn.loc.gov/2018047266

Cover art: World map with countries scaled to represent the percentage of foreign students studying in the United States, by country of origin. Source: www.ghemawat.com. 
To Serena, Harvey, and Callia.

You are my world. 
Presumably, if one is a factory worker, it is on the factory floor that one's politicization, one's consciousness, comes out in day-to-day struggle. And if I am an academic, and so long as I remain an academic, I must attempt to make the most important political input during those very many hours that I spend contributing to teaching or researching or whatever other aspects of academic life may come into play. -WALTER RODNEY, Walter Rodney Speaks (1990) 